\title{
Rhizobium oryzae sp. nov., isolated from the wild rice Oryza alta
}

\author{
Guixiang Peng, ${ }^{1}$ Qinghua Yuan, ${ }^{2}$ Huaxing Li, ${ }^{1}$ Wu Zhang ${ }^{2}$ \\ and Zhiyuan $\operatorname{Tan}^{2}$ \\ ${ }^{1}$ College of Resources and Environment, South China Agricultural University, Guangzhou 510642, \\ PR China \\ ${ }^{2}$ Provincial Key Laboratory of Plant Molecular Breeding, College of Agriculture, South China \\ Agricultural University, Guangzhou 510642, PR China
}

Correspondence

Zhiyuan Tan

zytan@scau.edu.cn

\begin{abstract}
During a study of endophytic nitrogen-fixing bacteria present in the wild rice species Oryza alta, eight novel isolates were obtained from surface-sterilized roots and classified in the genus Rhizobium on the basis of almost-complete 16S rRNA gene sequence analysis. These strains can nodulate Phaseolus vulgaris and Glycine max. The highly similar protein patterns, DNA fingerprint patterns of insertion sequence-based PCR (IS-PCR) and DNA-DNA hybridizations showed that these novel isolates were members of the same species. The closest phylogenetic relatives of the representative strain Alt $505^{\top}$ of the novel group were Rhizobium etli CFN $42^{\top}$ and Rhizobium indigoferae CCBAU $71714^{\top}$, with 96.2 and $96.0 \%$ 16S rRNA gene sequence similarity, respectively. Low DNA-DNA relatedness with the type strains of $R$. etli, $R$. indigoferae, Rhizobium hainanense, Rhizobium mongolense and Rhizobium galegae and differences in IS-PCR fingerprinting patterns, SDS-PAGE of proteins, antibiotic resistance, phenotypic tests and comparison of cellular fatty acids with Rhizobium species indicated that the novel group of isolates were distinct from previously described species. Based on these results, we propose to place them in a novel species, as Rhizobium oryzae sp. nov. The type strain is Alt $505^{\top}(=\mathrm{LMG}$ $24253^{\top}=$ CGMCC $1.7048^{\top}$ ).
\end{abstract}

Rhizobium species are traditionally considered as legume endosymbionts and have generally been isolated from nodules on leguminous plants (Amarger et al., 1997; de Lajudie et al., 1998; Lindström, 1989; Squartini et al., 2002; Valverde et al., 2006; van Berkum et al., 1998; Wang et al., 1998; Wei et al., 2002, 2003), with the exception of Rhizobium selenitireducens and Rhizobium daejeonense, isolated from bioreactors (Hunter et al., 2007; Quan et al., 2005), and Rhizobium cellulosilyticum, from sawdust of Populus alba (García-Fraile et al., 2007). Large populations of rhizobia are found both in the bulk soil and in the rhizospheres of legumes and other plants (Schloter et al., 1997; Segovia et al., 1991; Sullivan et al., 1996). Rhizobia are also found as viable cells in water, where they are able to infect and nodulate aquatic legumes, such as species of Neptunia (Zurdo-Piñeiro et al., 2004), Aeschynomene and

Abbreviation: IS-PCR, insertion sequence-based PCR.

The GenBank/EMBL/DDBJ accession numbers for the $16 \mathrm{~S}$ rRNA gene sequences of strains Alt $505^{\top}$ and Alt 501 are respectively EU056823 and EU056822.

A transmission electron micrograph of cells of strain Alt $505^{\top}$, detailed DNA-DNA hybridization results and a list of characters of two representative novel isolates are available as supplementary material with the online version of this paper.
Sesbania (Chaintreuil et al., 2000). More recently, it has been reported that these legume symbionts may also occur as endophytes in the roots of cereals, such as rice (Oryza breviligulata and Oryza sativa) (Chaintreuil et al., 2000; Elbeltagy et al., 2001; Engelhard et al., 2000; Ueda et al., 1995; Yanni et al., 1997), wheat and maize (Rosenblueth \& Martinez-Romero, 2004; Schloter et al., 1997). These findings have shown that rhizobia may colonize nonlegume plants, especially cereals, and can promote rice growth (Tan et al., 2001b; Yanni et al., 1997).

Wild rice is closely related to cultivated rice, O. sativa, which is the most important food crop in developing countries. During a study of endophytic nitrogen-fixing bacteria present in different wild rice species, a group of novel Rhizobium isolates was obtained from surfacesterilized roots of the wild rice Oryza alta. These Rhizobium isolates from wild rice potentially supply nitrogen to the rice plant and promote growth, and may serve as a valuable bioresource.

In this study, eight strains (Alt 501, Alt 503, Alt $505^{\mathrm{T}}$, Alt 509, Alt 521, Alt 525, Alt 530 and Alt 533) were isolated from $O$. alta growing in the Wild Rice Core Collection Nursery of South China Agricultural University. Methods 
of isolation and purification of nitrogen-fixing bacteria on YMA medium (Vincent, 1970) were described previously (Peng et al., 2006). To test the symbiotic characteristics of the novel isolates, Phaseolus vulgaris and Glycine max plants were inoculated as described by Chen et al. (1991), using Rhizobium etli CFN $42^{\mathrm{T}}$ and Sinorhizobium fredii USDA $205^{\mathrm{T}}$ inoculant, respectively, as positive controls. Noninoculated plants were used as negative controls. All eight novel strains were able to elicit effective nodules in $P$. vulgaris and G. max.

Whole-cell protein SDS-PAGE pattern analysis (Tan et al., 2001a) was used to group the novel Rhizobium isolates. The eight diazotrophic isolates had almost identical protein patterns, different from reference Rhizobium species (Fig. 1).

To evaluate the genotypic diversity of the novel isolates further, IS-PCR (insertion sequence-based PCR) fingerprinting was performed. The conditions of PCR amplification and electrophoresis were described previously (Peng et al., 2006). The eight novel isolates showed very similar patterns, but the patterns differed from those of strains of related Rhizobium species (Fig. 2). The amplified fragments of the novel isolates were 500-1000 bp long, whereas most of the reference Rhizobium strains yielded fragments of 600-2500 bp.

Nearly complete 16S rRNA gene sequences of representative strains Alt $505^{\mathrm{T}}$ and Alt 501 were obtained in this study according to the method described previously by Peng et al. (2006). The 16S rRNA gene sequences obtained and related reference sequences from GenBank were aligned using the CLUSTAL $\mathrm{W}$ software (Thompson et al., 1994). The tree topology was calculated by the maximumparsimony, maximum-likelihood (using PAUP 4.0; Swofford, 1998) and neighbour-joining (Saitou \& Nei, 1987) tree-building methods. The neighbour-joining tree was drawn and bootstrapped by using the TREECON software package (Van de Peer \& de Wachter, 1994) using 1000 replicates.

16S rRNA gene sequences of strains Alt $505^{\mathrm{T}}(1425 \mathrm{bp})$ and Alt 501 (1422 bp) were almost identical. The results of the phylogenetic analysis indicate that the strains from this study are related to members of the genus Rhizobium within the family Rhizobiaceae (Fig. 3). Their closest phylogenetic relatives are R. etli CFN $42^{\mathrm{T}}$ and Rhizobium indigoferae CCBAU $71714^{\mathrm{T}}$, with 96.2 and $96.0 \% 16 \mathrm{~S}$ rRNA gene sequence similarity, respectively.

Extraction and purification of total genomic DNA were carried out by using the method of Marmur (1961) and DNA base composition was determined by the thermal denaturation method $\left(T_{\mathrm{m}}\right)$ (De Ley, 1970; Marmur \& Doty, 1962). DNA from Escherichia coli K-12 was used as the standard for estimation of $\mathrm{G}+\mathrm{C}$ content. DNA-DNA relatedness was determined by the initial renaturation rate method (De Ley, 1970) in $2 \times$ SSC. The G $+C$ content of the genomic DNA of strain Alt $505^{\mathrm{T}}$ was $64.1 \pm 0.4 \mathrm{~mol} \%$. This value is in the range reported for other Rhizobium species (Jordan, 1984).

DNA-DNA relatedness among the novel isolates varied from 90 to $100 \%$, indicating that they were members of the same genomic species. DNA-DNA hybridization between Alt $505^{\mathrm{T}}$ and reference Rhizobium strains yielded low values ( $\leqslant 33 \%$; see Supplementary Table S1, available in IJSEM Online), well below the recommended value of $70 \%$ for species definition (Wayne et al., 1987).

Harvesting of cells and extraction of fatty acids were carried out as described by Sasser (1990) and fatty acid analysis was carried out as described by Peng et al. (2006). The cellular fatty acids of strain Alt $505^{\mathrm{T}}$ representing the novel group and the related strains $R$. etli CFN $42^{\mathrm{T}}$ and $R$. indigoferae CCBAU $71714^{\mathrm{T}}$ have three common components at retention times of 7.5, 10.0 and $10.4 \mathrm{~min}$. These common components together made up 84.4, 73.2 and $30.6 \%$ of the detected components of Alt $505^{\mathrm{T}}$, R. etli CFN

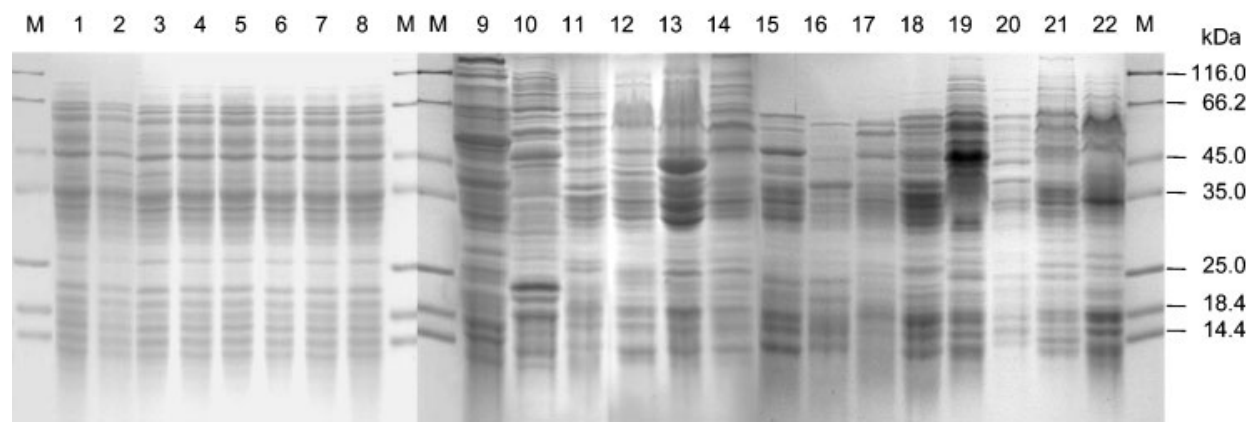

Fig. 1. SDS-PAGE whole-cell protein patterns of the nitrogen-fixing isolates from wild rice Oryza alta and strains of related species. Lanes: M, molecular-mass standards; 1 , strain Alt 530; 2, Alt 533; 3, Alt 509; 4, Alt 505 $;$; 5, Alt 521; 6, Alt 503; 7, Alt $501 ; 8$, Alt 525; 9, R. sullae IS123 ${ }^{\top} ; 10, R$. tropici type B CIAT 899 ${ }^{\top} ; 11, R$. loessense CCBAU $7190 \mathrm{~B}^{\top} ; 12, R$. leguminosarum USDA $2370^{\top} ; 13, R$. giardinii USDA $2914^{\top} ; 14, R$. galegae HAMBI $540^{\top} ; 15$, R. huautlense SO2 ${ }^{\top} ; 16$, $R$. yanglingense CCBAU $71623^{\top} ; 17, R$. tropici type A CFN 299; 18, R. mongolense USDA $1844^{\top} ; 19, R$. hainanense CCBAU $57015^{\top} ; 20, R$. etli CFN $42^{\top} ; 21, R$. indigoferae CCBAU $71714^{\top} ; 22$, R. undicola LMG $11875^{\top}$. 


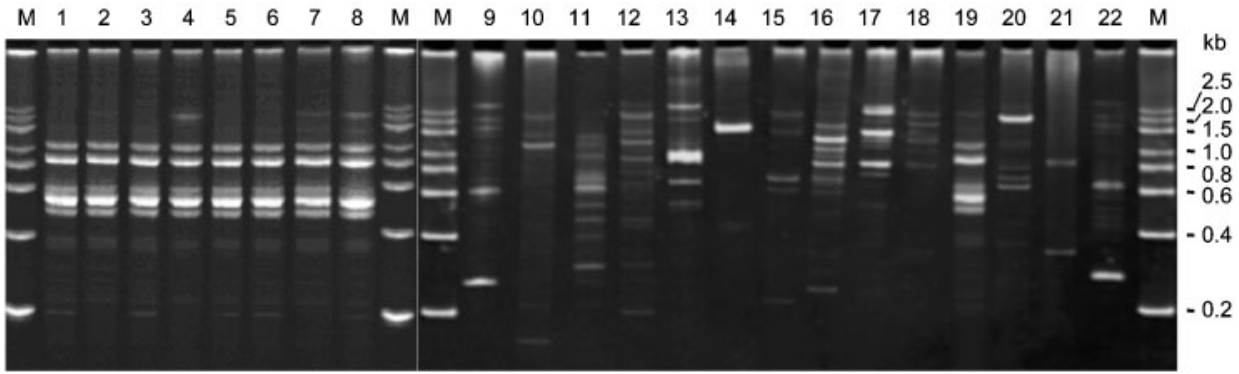

Fig. 2. IS-PCR fingerprinting patterns of the diazotrophic isolates from wild rice and strains of related species. Lanes: $M$, standard DNA marker; 1 , strain Alt 525; 2, Alt 533; 3, Alt 503; 4, Alt 505 ${ }^{\top} ; 5$, Alt 501; 6, Alt 509; 7, Alt 521; 8, Alt 530; 9 , R. mongolense USDA $1844^{\top} ; 10, R$. giardinii USDA $2914^{\top} ; 11, R$. indigoferae CCBAU $71714^{\top} ; 12, R$. loessense CCBAU $7190 \mathrm{~B}^{\top} ; 13, R$. leguminosarum USDA $2370^{\top} ; 14, R$. sullae IS123 ${ }^{\top} ; 15, R$. tropici type A CFN 299; 16, $R$. yanglingense CCBAU $71623^{\top} ; 17$, R. undicola LMG $11875^{\top} ; 18$, R. etli CFN $42^{\top} ; 19$, R. huautlense SO $2^{\top} ; 20$, R. galegae HAMBI 540'; 21 , $R$. hainanense CCBAU $57015^{\top} ; 22, R$. tropici type B CIAT $899^{\top}$.

$42^{\mathrm{T}}$ and $R$. indigoferae CCBAU $71714^{\mathrm{T}}$ (Table 1). Other components were present in some or all of strain Alt $505^{\mathrm{T}}$, $R$. etli CFN $42^{\mathrm{T}}$ and $R$. indigoferae CCBAU $71714^{\mathrm{T}}$. The relative abundance of each compound was also different in the tested strains.
Negatively stained cells (Cole \& Popkin, 1981) harvested from cultures grown in YMA liquid medium were used for the examination of flagella under a transmission electron microscope. Cell morphology was observed by using light microscopy and transmission electron microscopy

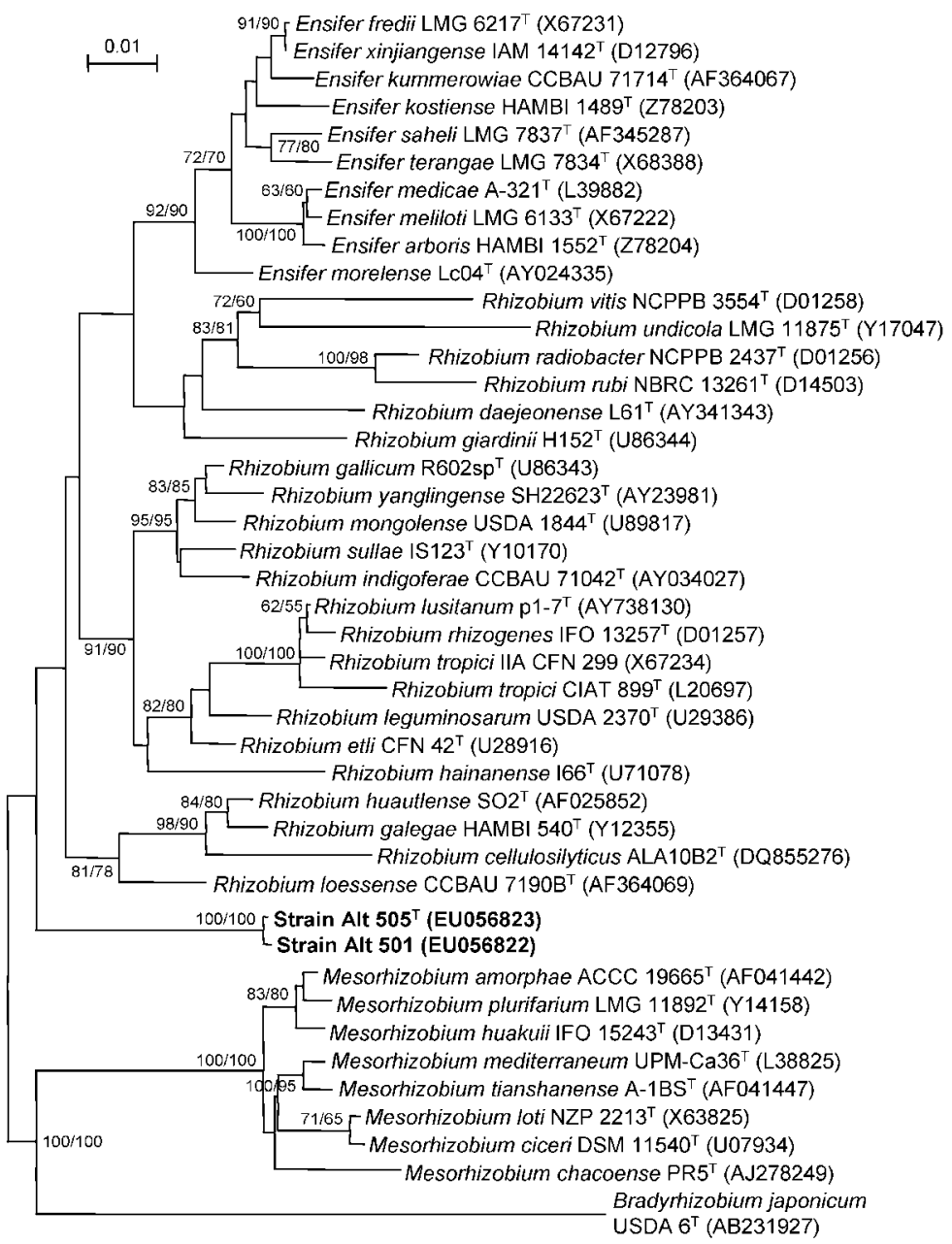

Fig. 3. Phylogenetic tree of $16 \mathrm{~S}$ rRNA gene sequences constructed with the neighbourjoining method showing relationships among strain Alt $505^{\top}$ and members of related genera. The sequence of Bradyrhizobium japonicum USDA $6^{\top}$ was used as an outgroup. Bootstrap percentages calculated by the neighbour joining/maximum-parsimony methods $\geqslant 55 \%$ are indicated at nodes. Bar, $1 \%$ nucleotide substitution. GenBank/EMBL/DDBJ accession numbers are shown in parentheses. 
Table 1. Cellular fatty acid compositions of strain Alt $505^{\top}$ and related strains

Fatty acids were determined as methyl esters by gas chromatography; values are percentages of total peak area.

\begin{tabular}{|c|c|c|c|}
\hline $\begin{array}{l}\text { Retention } \\
\text { time (min) }\end{array}$ & Alt $505^{\mathrm{T}}$ & $\begin{array}{c}\text { R. etli } \\
\text { CFN } 42^{\mathrm{T}}\end{array}$ & $\begin{array}{c}R . \text { indigoferae } \\
\text { CCBAU } 71714^{\mathrm{T}}\end{array}$ \\
\hline 3.9 & & & 2.4 \\
\hline 5.1 & & & 1.6 \\
\hline 6.0 & 1.1 & & 28.9 \\
\hline 6.3 & 1.0 & & 0.8 \\
\hline 7.0 & 1.8 & 9.2 & \\
\hline 7.1 & & & 7.3 \\
\hline 7.3 & 7.7 & & 5.4 \\
\hline 7.5 & 20.4 & 6.8 & 8.1 \\
\hline 8.5 & & & 21.6 \\
\hline 8.9 & & & 1.4 \\
\hline 10.0 & 64.0 & 61.5 & 21.2 \\
\hline 10.4 & 4.0 & 4.9 & 1.3 \\
\hline 11.7 & & 12.5 & \\
\hline 13.0 & & 5.1 & \\
\hline
\end{tabular}

(Hitachi-600). Cells are straight rods with polar flagella (Supplementary Fig. S1).

Utilization of sugars, amino acids, alcohols and organic acids as sole carbon sources was examined as described previously (Chen et al., 1988; Gao et al., 1994). Representative strains Alt $505^{\mathrm{T}}$ and Alt 501 were also characterized by using Biolog GN2 MicroPlates in comparison with reference Rhizobium species. Overnight cultures were used to inoculate the GN2 MicroPlates, according to the manufacturer's instructions. Antibiotic resistance tests and determination of $\mathrm{NaCl}$ tolerance and $\mathrm{pH}$ range for growth were performed in YMA, as described by Tan et al. (1999); phenotypic and biochemical features are summarized in Supplementary Table S2. Discriminative features among the novel isolates and their closest relatives, including $R$. etli and $R$. indigoferae, are shown in Table 2.

Based on the results described above, we propose to place the new isolates from wild rice in a novel species, Rhizobium oryzae sp. nov.

\section{Description of Rhizobium oryzae sp. nov.}

Rhizobium oryzae (o.ry'zae. L. gen. n. oryzae of rice, the origin of the first strains).

Cells are Gram-negative, motile, straight, non-sporeforming rods $(0.8-1.0 \times 1.4-1.8 \mu \mathrm{m})$ with polar flagella. Colonies on YMA medium are circular, cream coloured and semi-translucent, with a diameter of $3 \mathrm{~mm}$ within 3 days at $28{ }^{\circ} \mathrm{C}$. Growth occurs at $10-40{ }^{\circ} \mathrm{C}$ (optimum 28 $37^{\circ} \mathrm{C}$ ). The $\mathrm{pH}$ range for growth is $\mathrm{pH}$ 5.0-8.0 (optimum $\mathrm{pH}$ 6.0-7.0). $\mathrm{NaCl}$ inhibits growth above $1.5 \%$. Resistant to ampicillin $\left(100 \mu \mathrm{g} \mathrm{ml}^{-1}\right)$ and neomycin $\left(5 \mu \mathrm{g} \mathrm{ml}^{-1}\right)$. Tests for $o$-nitrophenyl- $\beta$-D-galactopyranosidase, urease,
Table 2. Discriminative features of two representative novel isolates and related species of the genus Rhizobium

Taxa: 1, strains Alt $505^{\mathrm{T}}$ and Alt 501; 2, Rhizobium leguminosarum (compiled from data for two strains; origin Phaseolus sp. and Vicia sp., USA); 3, R. tropici ( $n=2$; Leucaena leucocephala and Phaseolus vulgaris, Brazil); 4, R. galegae ( $n=2$; Galega orientalis, Finland); $5, R$. hainanense ( $n=2$; Desmodium sinuatum, China); 6, R. etli $(n=2$; Phaseolus vulgaris, Mexico); $7, R$. indigoferae ( $n=8$; Indigofera amblyantha, China). Numbers are percentages of strains testing positive. +, All strains positive; -, all strains negative. Data for reference species were compiled from Chen et al. (1997) and Wei et al. (2002).

\begin{tabular}{|c|c|c|c|c|c|c|c|}
\hline Feature & 1 & 2 & 3 & 4 & 5 & 6 & 7 \\
\hline \multicolumn{8}{|l|}{ Growth in/at: } \\
\hline $\mathrm{NaCl}(3.0 \%)$ & - & + & + & + & 50 & - & 13 \\
\hline pH 5.0 & + & - & + & + & + & - & - \\
\hline $40{ }^{\circ} \mathrm{C}$ & + & - & 50 & - & + & - & - \\
\hline \multicolumn{8}{|c|}{ Utilization as sole carbon source of: } \\
\hline D-Amygdalin & - & + & - & 50 & - & - & 13 \\
\hline D-Arabinose & + & + & + & + & + & + & - \\
\hline D-Arabitol & - & - & 50 & - & + & + & 75 \\
\hline Calcium malonate & - & + & - & + & - & - & - \\
\hline Dulcitol & + & + & - & + & + & - & + \\
\hline i-Erythritol & + & - & + & 50 & + & - & 25 \\
\hline Lactose & + & + & 50 & + & - & - & 88 \\
\hline Salicin & - & + & - & + & - & + & + \\
\hline D-Ribose & - & + & + & - & + & + & 25 \\
\hline D-Gluconate & + & - & - & 50 & + & + & 75 \\
\hline Sucrose & + & - & - & + & + & + & + \\
\hline Tartrate & - & 50 & 50 & 50 & - & + & - \\
\hline Xylose & + & + & + & - & + & + & + \\
\hline Glycine & - & - & + & 50 & + & + & + \\
\hline \multicolumn{8}{|c|}{ Antibiotic resistance $\left(\mu \mathrm{g} \mathrm{ml}^{-1}\right)$} \\
\hline Ampicillin (100) & + & + & + & + & + & + & 13 \\
\hline Chloramphenicol (100) & - & - & + & - & + & - & - \\
\hline Erythromycin (100) & - & - & - & + & + & - & 13 \\
\hline Kanamycin (5) & - & + & + & + & + & + & - \\
\hline Streptomycin (300) & - & - & + & - & - & + & - \\
\hline
\end{tabular}

cytochrome oxidase and the Voges-Proskauer reaction are positive. The following compounds are used as sole carbon sources: L- and D-arabinose, L-arabitol, cellobiose, $\mathrm{N}$ acetyl-D-glucosamine, adonitol, L-alanine, i-erythritol, Dfructose, D-fucose, D-galactose, gentiobiose, $\alpha$-D-glucose, myo-inositol, $\alpha$-D-lactose, maltose, D-mannitol, D-mannose, melibiose, succinic acid, citric acid, methyl $\beta$-Dglucoside, D-psicose, raffinose, L-rhamnose, D-sorbitol, sucrose, trehalose, turanose, methyl pyruvate, D-gluconic acid, monomethyl succinate, D-galacturonic acid, Dglucuronic acid, $\beta$-hydroxybutyric acid, $\alpha$-ketoglutaric acid, DL-lactic acid, quinic acid, D-saccharic acid, bromosuccinic acid, L-alanyl glycine, glycerol, L-asparagine, Laspartic acid, L-glutamic acid, L-histidine, L-proline, hydroxy-L-proline, L-serine, L-threonine, $\gamma$-aminobutyric acid, urocanic acid, uridine, D-xylose, glucose 1-phosphate, glucose 6-phosphate, dulcitol, L-malate, D-ribose, xylose, 
sorbitol and D-tagatose. The $\mathrm{G}+\mathrm{C}$ content of genomic DNA of the type strain is $64.1 \pm 0.4 \mathrm{~mol} \%$.

The type strain, strain Alt $505^{\mathrm{T}}\left(=\mathrm{LMG} 24253^{\mathrm{T}}=\mathrm{CGMCC}\right.$ $1.7048^{\mathrm{T}}$ ), and seven other strains were isolated from the wild rice species Oryza alta.

\section{Acknowledgements}

This work was supported by National Natural Science Foundation of China (NSFC, 30470002) and the Scientific Research Foundation for the Returned Overseas Chinese Scholars, State Education Ministry (SRF for ROCS, SEM).

\section{References}

Amarger, N., Macheret, V. \& Laguerre, G. (1997). Rhizobium gallicum sp. nov. and Rhizobium giardinii sp. nov., from Phaseolus vulgaris nodules. Int J Syst Bacteriol 47, 996-1006.

Chaintreuil, C., Giraud, E., Prin, Y., Lorquin, J., Bâ, A., Gillis, M., de Lajudie, P. \& Dreyfus, B. (2000). Photosynthetic bradyrhizobia are natural endophytes of the African wild rice Oryza breviligulata. Appl Environ Microbiol 66, 5437-5447.

Chen, W. X., Yan, G. H. \& Li, J. L. (1988). Numerical taxonomic study of fast-growing soybean rhizobia and proposal that Rhizobium fredii be assigned to Sinorhizobium gen. nov. Int J Syst Bacteriol 38, 392-397.

Chen, W. X., Li, G. S., Qi, Y. L., Wang, E. T., Yuan, H. L. \& Li, J. L. (1991). Rhizobium huakuii sp. nov., isolated from the root nodules of Astragalus sinicus. Int J Syst Bacteriol 41, 275-280.

Chen, W. X., Tan, Z. Y., Gao, J. L., Li, Y. \& Wang, E. T. (1997). Rhizobium hainanense sp. nov., isolated from tropical legumes. Int $J$ Syst Bacteriol 47, 870-873.

Cole, R. M. \& Popkin, T. J. (1981). Electron microscopy. In Manual of Methods for General Bacteriology, pp. 34-51. Edited by P. Gerhardt, R. G. E. Murray, R. N. Costilow, E. W. Nester, W. A. Wood, N. R. Krieg \& G. B. Phillips. Washington, DC: American Society for Microbiology.

de Lajudie, P., Laurent-Fulele, E., Willems, A., Torck, U., Coopman, R., Collins, M. D., Kersters, K., Dreyfus, B. \& Gillis, M. (1998). Allorhizobium undicola gen. nov., sp. nov., nitrogen-fixing bacteria that efficiently nodulate Neptunia natans in Senegal. Int J Syst Bacteriol 48, 1277-1290.

De Ley, J. (1970). Reexamination of the association between melting point, buoyant density, and chemical base composition of deoxyribonucleic acid. J Bacteriol 101, 738-754.

Elbeltagy, A., Nishioka, K., Sato, T., Suzuki, H., Ye, B., Hamada, T., Isawa, T., Mitsui, H. \& Minamisawa, K. (2001). Endophytic colonization and in planta nitrogen fixation by a Herbaspirillum sp. isolated from wild rice species. Appl Environ Microbiol 67, 5285-5293.

Engelhard, M., Hurek, T. \& Reinhold-Hurek, B. (2000). Preferential occurrence of diazotrophic endophytes, Azoarcus spp., in wild rice species and land races of Oryza sativa in comparison with modern races. Environ Microbiol 2, 131-141.

Gao, J. L., Sun, J. G., Li, Y., Wang, E. T. \& Chen, W. X. (1994). Numerical taxonomy and DNA relatedness of tropical rhizobia isolated from Hainan province of China. Int J Syst Bacteriol 44, 151-158.

García-Fraile, P., Rivas, R., Willems, A., Peix, A., Martens, M., Martínez-Molina, E., Mateos, P. F. \& Velázquez, E. (2007). Rhizobium cellulosilyticum sp. nov., isolated from sawdust of Populus alba. Int J Syst Evol Microbiol 57, 844-848.
Hunter, W. J., Kuykendall, L. D. \& Manter, D. K. (2007). Rhizobium selenireducens sp. nov.: a selenite-reducing $\alpha$-Proteobacteria isolated from a bioreactor. Curr Microbiol 55, 455-460.

Jordan, D. C. (1984). Genus I. Rhizobium Frank 1889, 338 ${ }^{\mathrm{AL}}$. In Bergey's Manual of Systematic Bacteriology, vol. 1, pp. 235-242. Edited by N. R. Krieg \& J. G. Holt. Baltimore: Williams \& Wilkins.

Lindström, K. (1989). Rhizobium galegae, a new species of legume root nodule bacteria. Int J Syst Bacteriol 39, 365-367.

Marmur, J. (1961). A procedure for the isolation of deoxyribonucleic acid from microorganisms. J Mol Biol 3, 208-218.

Marmur, J. \& Doty, P. (1962). Determination of the base composition of deoxyribonucleic acid from its thermal denaturation temperature. $J$ Mol Biol 5, 109-118.

Peng, G., Wang, H., Zhang, G., Hou, W., Liu, Y., Wang, E. T. \& Tan, Z. (2006). Azospirillum melinis sp. nov., a group of diazotrophs isolated from tropical molasses grass. Int J Syst Evol Microbiol 56, 1263-1271.

Quan, Z. X., Bae, H. S., Baek, J. H., Chen, W. F., Im, W. T. \& Lee, S. T. (2005). Rhizobium daejeonense sp. nov., isolated from a cyanide treatment bioreactor. Int J Syst Evol Microbiol 55, 2543-2549.

Rosenblueth, M. \& Martinez-Romero, E. (2004). Rhizobium etli maize populations and their competitiveness for root colonization. Arch Microbiol 181, 337-344.

Saitou, N. \& Nei, M. (1987). The neighbor-joining method: a new method for reconstructing phylogenetic trees. Mol Biol Evol 4, 406-425.

Sasser, M. (1990). Identification of bacteria by gas chromatography of cellular fatty acids, MIDI Technical Note 101. Newark, DE: MIDI Inc.

Schloter, M., Wiehe, W., Assmus, B., Steindl, H., Becke, H., Höflich, G. \& Hartmann, A. (1997). Root colonization of different plants by plantgrowth-promoting Rhizobium leguminosarum bv. trifolii R39 studied with monospecific polyclonal antisera. Appl Environ Microbiol 63, 2038-2046.

Segovia, L., Piñero, D., Palacios, R. \& Martínez-Romero, E. (1991). Genetic structure of a soil population of nonsymbiotic Rhizobium leguminosarum. Appl Environ Microbiol 57, 426-433.

Squartini, A., Struffi, P., Döring, H., Selenska-Pobell, S., Tola, E., Giacomini, A., Vendramin, E., Velázquez, E., Mateos, P. F. \& other authors (2002). Rhizobium sullae sp. nov. (formerly 'Rhizobium hedysari), the root-nodule microsymbiont of Hedysarum coronarium L. Int J Syst Evol Microbiol 52, 1267-1276.

Sullivan, J. T., Eardly, B. D., van Berkum, P. \& Ronson, C. W. (1996). Four unnamed species of nonsymbiotic rhizobia isolated from the rhizosphere of Lotus corniculatus. Appl Environ Microbiol 62, 28182825.

Swofford, D. L. (1998). PAUP*: Phylogenetic analysis using parsimony (and other methods), version 4. Sunderland, MA: Sinauer Associates.

Tan, Z. Y., Wang, E. T., Peng, G. X., Zhu, M. E., Martínez-Romero, E. \& Chen, W. X. (1999). Characterization of bacteria isolated from wild legumes in the north-western regions of China. Int J Syst Bacteriol 49, 1457-1469.

Tan, Z., Hurek, T., Gyaneshwar, P., Ladha, J. K. \& Reinhold-Hurek, B. (2001a). Novel endophytes of rice form a taxonomically distinct subgroup of Serratia marcescens. Syst Appl Microbiol 24, 245-251.

Tan, Z., Hurek, T., Vinuesa, P., Muller, P., Ladha, J. K. \& ReinholdHurek, B. (2001b). Specific detection of Bradyrhizobium and Rhizobium strains colonizing rice (Oryza sativa) roots by $16 \mathrm{~S}-23 \mathrm{~S}$ ribosomal DNA intergenic spacer-targeted PCR. Appl Environ Microbiol 67, 3655-3664.

Thompson, J. D., Higgins, D. G. \& Gibson, T. J. (1994). Clustal W: improving the sensitivity of progressive multiple sequence alignment 
through sequence weighting, position-specific gap penalties and weight matrix choice. Nucleic Acids Res 22, 4673-4680.

Ueda, T., Suga, Y., Yahiro, N. \& Matsuguchi, T. (1995). Remarkable $\mathrm{N}_{2^{-}}$ fixing bacterial diversity detected in rice roots by molecular evolutionary analysis of nifH gene sequences. J Bacteriol 177, 1414-1417.

Valverde, A., Igual, J. M., Peix, A., Cervantes, E. \& Velázquez, E. (2006). Rhizobium lusitanum sp. nov. a bacterium that nodulates Phaseolus vulgaris. Int J Syst Evol Microbiol 56, 2631-2637.

van Berkum, P., Beyene, D., Bao, G., Campbell, T. A. \& Eardly, B. D. (1998). Rhizobium mongolense sp. nov. is one of three rhizobial genotypes identified which nodulate and form nitrogen-fixing symbioses with Medicago ruthenica [(L.) Ledebour]. Int J Syst Bacteriol 48, 13-22.

Van de Peer, Y. \& de Wachter, R. (1994). TREECON for Windows: a software package for the construction and drawing of evolutionary trees for the Microsoft Windows environment. Comput Appl Biosci 10, 569-570.

Vincent, J. M. (1970). The cultivation, isolation and maintenance of rhizobia. In A Manual for the Practical Study of the Root-Nodule Bacteria, pp. 1-13. Edited by J. M. Vincent. Oxford: Blackwell Scientific.

Wang, E. T., van Berkum, P., Beyene, D., Sui, X. H., Dorado, O., Chen, W. X. \& Martínez-Romero, E. (1998). Rhizobium huautlense sp. nov., a symbiont of Sesbania herbacea that has a close phylogenetic relationship with Rhizobium galegae. Int J Syst Bacteriol 48, 687-699.
Wayne, L. G., Brenner, D. J., Colwell, R. R., Grimont, P. A. D., Kandler, O., Krichevsky, M. I., Moore, L. H., Moore, W. E. C., Murray, R. G. E. \& other authors (1987). International Committee on Systematic Bacteriology. Report of the ad hoc committee on reconciliation of approaches to bacterial systematics. Int J Syst Bacteriol 37, 463-464.

Wei, G. H., Wang, E. T., Tan, Z. Y., Zhu, M. E. \& Chen, W. X. (2002). Rhizobium indigoferae sp. nov. and Sinorhizobium kummerowiae sp. nov., respectively isolated from Indigofera spp. and Kummerowia stipulacea. Int J Syst Evol Microbiol 52, 2231-2239.

Wei, G. H., Tan, Z. Y., Zhu, M. E., Wang, E. T., Han, S. Z. \& Chen, W. X. (2003). Characterization of rhizobia isolated from legume species within the genera Astragalus and Lespedeza grown in the Loess Plateau of China and description of Rhizobium loessense sp. nov. Int J Syst Evol Microbiol 53, 1575-1583.

Yanni, Y. G., Rizk, R. Y., Corich, V., Squartini, A., Ninke, K., PhilipHollingsworth, S., Orgambide, G., De Bruijn, F., Stoltzfus, J. \& other authors (1997). Natural endophytic association between Rhizobium leguminosarum bv. trifolii and rice roots and assessment of its potential to promote rice growth. Plant Soil 194, 99-114.

Zurdo-Piñeiro, J. L., Velázquez, E., Lorite, M. J., Brelles-Mariño, G., Schröder, E. C., Bedmar, E. J., Mateos, P. F. \& Martínez-Molina, E. (2004). Identification of fast-growing rhizobia nodulating tropical legumes from Puerto Rico as Rhizobium gallicum and Rhizobium tropici. Syst Appl Microbiol 27, 469-477. 